\title{
Etkili Vatandaşlık Eğitiminde Değerler Eğitimi: Sosyal Bilgiler Öğretmenlerinin Düşünceleri*
}

\section{Values Education in Effective Citizenship Education: Thoughts of Social Studies Teachers **}

\author{
Emine KARASU-AVGI, Dr. Öğr. Üyesi. \\ Kastamonu Üniversitesi, Eğitim Fakültesi, Türkiye. \\ eavci@kastamonu.edu.tr \\ http://orcid.org/0000-0002-3135-2557 \\ Melike FAIZZ, Sorumlu Yazar, Dr. Öğr. Üyesi. \\ Kastamonu Üniversitesi, Eğitim Fakültesi, Türkiye. \\ mfaiz@kastamonu.edu.tr \\ http://orcid.org/0000-0001-8070-6086 \\ Saim TURAN, Araştırma Görevlisi. \\ Akdeniz Üniversitesi, Eğitim Fakültesi, Türkiye. \\ turansaim@gmail.com \\ http://orcid.org/0000-0003-0298-8609
}

ISSN: $1303-880 \mathrm{X}$

e-ISSN: 2667-7504

http://ded.dem.org.tr

Makale Türü / Article Type:

Araştırma Makalesi / Research Article

Geliş Tarihi / Received Date: 05.12.2019

Kabul Tarihi / Accepted Date: 01.04.2020

Yayın Tarihi / Published Date: 25.06.2020

Tr/En: $\operatorname{Tr}$

Intihal / Plagiarism: Bu makale, en az iki hakem tarafindan incelendi ve intihal içermediği teyit edildi. / This article has been reviewed by at least two referees and scanned via a plagiarism software.
Atıf/Citation: Karasu-Avc1, E., Faiz, M., Turan, S. (2020). Etkili vatandaşlık eğitiminde değerler eğitimi: Sosyal bilgiler öğretmenlerinin düşünceleri. Değerler Ĕgitimi Dergisi,18 (39), s.263-296. https://doi.org/10.34234/ded.655916

* II. Uluslararası Eğitim ve Değerler Sempozyumu (ISEOVA II)'da sözlü olarak sunulmuş bildirinin çalışma grubu genişletilmiş halidir.

** This study is an expanded version of the paper presented at the 2nd International Symposium on Education and Values (ISEOVA II). 
Öz: Etkili vatandaşlık; haklarını bilmek, kullanmak, sorumluluklarının bilincinde olmak, bu sorumlulukları yerine getirmek ve diğer insanların haklarına saygı duymaktır. Değerler de vatandaşlık anlayışının oluşturulmasında toplumsal tutum ve beklentileri yansıtmaktadır. Değerleri benimsemiş bireylere hem etkili vatandaşların yetiştirilmesi hem de toplumsal devamlılık için ihtiyaç duyulmaktadır. Dolayısıyla değerlerin ve Sosyal Bilgiler dersinin etkili vatandaş profilinin geliştirilmesinde önemli rolü bulunmaktadır. Sosyal Bilgiler dersinin temel amacının vatandaşlık eğitimi olduğu düşünüldügün̈de etkili vatandaş profilinin geliştirilmesinde Sosyal Bilgiler dersinin önemli bir ayağı olan değerler ve değerler eğitiminin önemi anlaşılmaktadır. Bu araştırmanın amacı etkili vatandaşlık eğitiminde değerler ve değerler eğitimine yönelik Sosyal Bilgiler öğretmenlerinin düşüncelerini ortaya koymaktır. Araştırma olgubilim deseninde tasarlanmıştır. Araştırmanın çalışma grubunu Türkiye'nin çeşitli illerinde görev yapan ve araştırmaya katılmayı gönüllü olarak kabul eden Sosyal Bilgiler öğretmenleri oluşturmaktadır. Araştırmada veriler elektronik posta yoluyla gönderilen yapılandırılmış görüşme formuyla elde edilmiştir. Veriler araştırma soruları çerçevesinde betimsel analiz yoluyla çözümlenmiştir. Sosyal Bilgiler öğretmenlerinden elde edilen veriler vatandaşlık ve değerler arasındaki ilişkiyi değerlerin vatandaşlığın şekillenmesine katkı sağladığı; etkili bir vatandaşın vatanseverlik, sorumluluk, dürüstlük, çalışkanlık, bilimsellik, saygı ve eşitlik gibi değerlere sahip olacağı; Sosyal Bilgiler dersinin yine benzer değerlerle etkili vatandaşlık eğitimine katkı sağladığı ve Sosyal Bilgiler Öğretim Programı'nda verilen değerlerin etkili vatandaşlık eğitimi için yeterli olduğu yönündedir.

Anahtar Kelimeler: Etkili vatandaşlık, Değerler, Sosyal bilgiler, Öğretmen, Düşünce.

$\&$

Abstract: Effective citizenship; is the knowledge of one's rights and how to claim them, being aware of the responsibilities, and how to fulfill these responsibilities and to respect the rights of other people. Values reflect social attitudes and expectations in the formation of citizenship concept. Individuals who embrace values are needed both for the upbringing of effective citizens and for social continuity. Therefore, Social Studies courses have an important role in developing effective citizen profile. The aim of this study is to reveal the Social Studies teachers' opinions about values and values education in terms of effective citizenship education. The research made use of the Phenomenological 
design. Study group of the research consist of 19 teachers who is working in various cities of Turkey. The data were obtained through a structured interview form. The data were analyzed by descriptive analysis. As a result of this study, Social Studies teachers explain the relationship between citizenship and values that which values contribute to the formation of citizenship. Teachers also state that Social Studies course contributes to effective citizenship education with similar values and they believe the values given in the Social Studies Curriculum are sufficient for effective citizenship education.

Keywords: Effective citizenship, Values, Social studies, Teacher.

(The Extended Abstract is at the end of the article)

\section{Giriş}

Vatandaşlık, devletin bireye sunduğu temel hak ve özgürlüklere sahip yasal bir statüdür (Üstel, 2005). Birey ve devlet arasındaki ilişkilerden doğmuş olup, bireyin devlete devletin de bireye karşı sorumluluklarını kapsar (Doğanay, 2005). Vatandaş, toplumsal hak ve sorumlulukları çerçevesinde bilgi sahibi olan, toplumun bugünü ve geleceği ile ilgili konularda fikir sahibi ve karar alma mekanizmalarına aktif olarak katılan kişidir (Demircioğlu, 2008). Vatandaşlık, belirli bir vatana aidiyet duyma ve o vatana ait ortak değerler, yasal düzenlemeler, örf, adetler gibi toplumsal düzenlemelere uyma davranışıdır (Uğurlu, 2011). Vatandaşlık hem bireyin psikolojisi hem de yasal statüsü ile ilgili verileri içermektedir (Çarkoğlu ve Kalaycıoğlu, 2014). Vatandaşlık genel olarak bir ülkede ikamet etme hakkı, o ülkenin yasalarına göre korunma hakları ve bu haklar dolayısıyla ortaya çıkan sorumluluklara sahip olma olarak ifade edilebilir (Shin ve Bernardz, 2018). Devletlerin anayasalarında da genellikle vatandaşlık, doğum yeri ve nesep esasına göre tanımlanmaktadır (Türkiye Büyük Millet Meclisi Araştırma Merkezi [TBMMAM], 2011). Bu anlamda vatandaşlık hukuki, siyasi ve sosyo-ekonomik boyutları olan çok yönlü bir kavramdır.

Yerleşim yerlerinin kurulmaya başladığı dönemlerden beri toplumların en büyük hedeflerinden birisi toplumun beklenti ve ihtiyaçlarını özümsemiş bireyler yetiştirmek olmuştur. Çünkü toplumların devamlılığını sağlayabilmek ve toplumdaki ihtiyaçları karşılayabilmek topluma aidiyet duygusuyla bağlanmış bireylerle mümkündür. Vatandaşlık kavramı, toplumsal hayatta farklı şekillerde ele alınmaktadır. Bunlardan birisi de etkili vatandaşlık kavramıdır. 
Etkili vatandaşlık; haklarını bilmek, kullanmak, sorumluluklarının bilincinde olmak, bu sorumlulukları yerine getirmek ve diğer insanların haklarına saygı duymaktır. Demokratik toplumlarda bireylerin bilgi, beceri ve değerler boyutunda vatandaşlığın gerektirdiği özelliklere sahip olmasıdır (National Council for the Socal Studies [NCSS], 2010). Etkili vatandaş, yaşadığı kültürü benimseyerek onu geliştirmeye çaba harcayan ve bu yolda uğraş veren kişiler olarak tanımlanabilir (Safran, 2008). Correia (2002) etkili vatandaş kavramını, bireylerin diğer bireylere, topluma ve devlete karşı hak ve sorumluluklarını kullanma yetkisine sahip olması olarak açıklamaktadır. Andrews, Cowell, Downe, Martin, Turner (2008) etkili vatandaşlığı topluma uyum sağlama ve demokratik kararlar verebilme olarak ifade etmektedirler. Etkili vatandaş; aktif, üreten, düşünen, sorgulayan, geliştiren ve problem çözme becerilerine sahip (Phillips, 2003; Kan, 2009a); günümüz dünyasına ayak uydurabilen, teknoloji ve dijital okuryazarlığa sahip bireylerdir (Miller 1995; Berson ve Berson 2003). Kisaca etkili vatandaşlık bireyleri toplum hayatına hazırlayan ve toplumsal hayatta rol almasını sağlayan nitelikler olarak düşünülebilir (Milli Eğitim Bakanlığ1 [MEB], 2018).

Ülkenin ve toplumun devamlılığını sağlamak ve toplumsal yapıyı güçlendirerek ileriye götürmek bireyleri ancak ortak amaçlarda birleştirerek ve vatandaşlık bilinci kazandırarak sağlanabilir. Vatandaşlık bilinci ülkenin siyasi yapısını, eğitim sistemini, işyeri verimliliğini, sosyal refahı ve genel olarak gelişmişlik düzeyini etkiler (Hablemitoğlu ve Özmete, 2012). Vatandaşlık bilincini taşıyan bireyler ülkesini ve ailesini koruyan ve seven, ailesi ve topluma karşı görev ve sorumluluklarının farkında, eleştirel düşünebilen ve mantıklı kararlar verebilen, diğer kişilerle iyi iletişime sahip ve empati kurabilen, toplum için çaba harcayan, dürüst, çevresindeki problemlerin farkında ve bu problemlere duyarlı olan ve güncel olayları takip eden kişilerdir (Kızlay, 2015). Gelişen, değişen ve güncellenen toplum ihtiyaçları ve eğilimleri dikkate alındığında vatandaşlık eğitiminin de bu yönde gelişimi ve değişiminin bir gereklilik olduğu ortaya çıkmaktadır (Tezci, 2002).

Etkili vatandaşların yetiştirilmesi için hiç şüphesiz okullara, öğretmenlere ve program hazırlayıcılara önemli görevler düşmektedir. Çünkü çağımızda bireylerin yaşadıkları topluma doğru ve en etkili bir şekilde adapte olmalarını sağlamak amacıyla vatandaşlık eğitimi ile ilgili dersler okutulmaktadır. İyi ve etkili bir vatandaşın sahip olduğu kazanım, beceri ve davranışları elde edebilecekleri doğru yaklaşımlar doğru eğitim ve öğretim araçları ve buna uygun bir öğretim 
programının gerekliliğini ortaya çıkarmaktadır (Phillips, 2003; Kan, 2009b). Etkili vatandaşlık, genel olarak vatandaşlık ve bireyleri topluma ve toplumla ilgili boyutlara hazırlama bakımından tüm derslerin genel olarak amaçlarından biri olsa da bu amaçla ortaya çıkmış olan Sosyal Bilgiler dersinin temel amaçlarından birisidir. Nitekim Sosyal Bilgiler dersinin amaçlarında bireylerin iyi ve etkili birer vatandaş olarak yetiştirilmesine yönelik hedefler görülmektedir (MEB, 2018). Bir ilk ve ortaokul dersi olan Sosyal Bilgilere düşen en büyük görev bireyleri topluma uyumlu, toplumu geliştirebilecek, toplumsal sorunlarla ilgilenen vatandaşlar olarak yetiştirmektir. Bu görevin ilk ve ortaokul düzeyinde verilen bir dersin temel amaçlarından biri olması (Ersoy, 2007; Yeşil, 2002) vatandaşlık eğitimine erken yaşlardan itibaren başlanmasının önemini göstermektedir. Vatandaşlık eğitimi ile bireylerin yaşadıkları topluma uyumlu bireyler olarak yetiştirilmesi hedeflenir (Çelik, 2008). Demokratik yönetimlerde toplumun yönetimi, geleceği ile ilgili kararlarda aktif katılımcı olması beklenen bireylerin vatandaşlık eğitimi sayesinde doğru adımlar atabileceği ve doğru kararlar alınmasında aktif rol oynayabileceği düşünülen bireyler ile sağlanır. Bu nedenle okullarda öğrencilere sunulan vatandaşlık eğitimi ile öğrencilerin bireyler olarak içinde yaşadıkları toplumun sorun ve beklentilerinden haberdar olarak bu sorunlara çözüm üretebilecek, bu sorunlarla mücadele edebilecek donanıma sahip olmaları beklenmektedir (Demircioğlu, 2008). Toplumda yaşayan her bireyin bilgili, problem çözücü, katılımc1, sorumluluk sahibi ve toplumsal sorunlara duyarlı bir varlık olarak yaşaması etkili vatandaş olmanın temel nitelikleridir.

Etkili ve sorumlu bir vatandaşın sahip olması gereken temel özelliklerden biri de değerleri benimsemesidir (NCSS, 2012). Değer kavramına ilişkin literatürde çeşitli tanımlamaların yapıldığı görülmektedir. Halstead ve Taylor (2002) değer kavramını, davranışlara rehberlik eden ilkeler, temel inançlar ve belirli eylemlerin iyi veya arzu edilebilir olduğuna karar verilen standartlar olarak; Raths, Harmin ve Simon (1966) değeri, bireyin gurur duyduğu inanç, duygu, davranış ve zorlama olmaksızın birçok alternatiften düşünülerek seçilmiş ve tekrar edilebilen hareketler olarak tanımlamaktadırlar. Ayrıca değer kavramı, sosyal hayatın açıklanmasında yararlanılan (Yazıc1, 2014) ve aynı zamanda vatandaşlık tipinin oluşturulmasında toplumsal tutum ve beklentileri yansitan bir inanç sistemi olarak da ifade edilebilir (Rokeach, 1973). Bir toplumun geleceği değerlerini benimsemiş ve bu değerleri ete kemiğe büründüren bireylerin varlığına bağlıdır. Değerler bireylerin problemlerle başa çıkabilmesinde ve eyleme geçmesinde güç kaynağ1dırlar (MEB, 2018). Değerlerin bir başka özelliği de bireyleri etrafında birleştirebilmesidir. $\mathrm{Bu}$ durum değerlerin zaman içerisinde oluşarak anonimleşmiş 
olması ile açıklanabilir. Değerleri benimsemiş bireylere hem etkili vatandaşların yetiştirilmesi hem de toplumsal devamllık için ihtiyaç duyulmaktadır. Nitekim ihtiyaçlar, eğilimler ve gelişmelerle tanımı farklılaşan vatandaşlığın tam olarak gerçekleşebilmesi için bireyin içinde yaşadığı toplumun değerlerini öğrenerek onları içselleştirmesi gerekmektedir. Değerler toplumun, grubun ya da birlikte yaşayan insanların hayatlarında kurdukları ve zaman içerisinde gelişen düzenlerini koruyarak devamını sağlamak amacıyla o toplumun çoğunluğu tarafindan kabul edilmiş ortak düşünce, ahlaki ilkeler ve toplumsal kurallardır. Değerler, vatandaşlık tipinin oluşturulmasında toplumsal tutum ve beklentileri yansıtmaktadır. Değerleri benimsemiş bireylere hem etkili vatandaşların yetiştirilmesi hem de toplumsal devamlılık için ihtiyaç duyulmaktadır.

Sosyal Bilgiler dersi, amaç ve kapsam olarak vatandaşlığı ele alan bir derstir. Sosyal Bilgiler dersinin ortaya çıkışı amacı ve yapısı itibariyle bireyleri topluma uyumlu birer vatandaş olarak yetiştirmek olduğu söylenebilir. Bu dersin temel amacının vatandaşlık eğitimi olduğu düşünüldüğünde etkili vatandaş profilinin geliştirilmesinde Sosyal Bilgiler dersinin önemli bir ayağı olan değerler ve değerler eğitiminin önemi anlaşılmaktadır. Bu amaca ulaşmak için Sosyal Bilgiler öğretmenlerinin etkili vatandaşlık eğitiminde değerler ve değerler eğitimine yönelik düşüncelerinin belirlenmesi gerekmektedir.

Yabanc1 literatür incelendiğinde farklı eğitim düzeylerinde görev yapan öğretmenlerin değerlerini kültürler arası karşılaştırmalar şeklinde inceleyen ve öğretmenlerin, ahlak eğitimindeki görevlerini belirlemeye yönelik araştırmalara (Leblanch, 2007; Coombs-Richardson ve Tolson, 2005; Veugelers ve Kat, 2003); ergenlerin ve gençlerin değerlerini çeşitli değişkenler çerçevesinde ele alan araştırmalara (Owens, 2005; Silfver, 2007; Miethe, 2001; Bohning, Hodson, Foote, McGee ve Young, 1998); değer öğretimi, karakter eğitimi, karşılaş1lan sorunlar ve hizmet öncesi öğretmen eğitiminde değerler eğitimine yönelik araştırmalara (Thornberg, 2008; Lewis, 2007; Chandler, 2005; Ledford, 2005; Moore, 2005; Willemse, Lunenberg ve Korthagen, 2005; Revell, 2002; Veugelers, 2000); değerlerin öğretimi ve eğitimiyle (Wright, 2005; Farmer, 2010) ilgili araştırmalara rastlanmaktadır.

Türkiye'deki literatür incelendiğinde ise öğrencilerin değerleri kazanma düzeylerini (Beldağ, 2012); Sosyal Bilgiler Dersi Öğretim Programı uygulama kılavuzunda yer alan etkinliklerin değer eğitimi yaklaşımları açısından durumunu (Yiğittir ve Kaymakc1, 2012); ders kitaplarındaki değerlere karşı tutumları (Tahiroğlu, 2011); ilköğretim beşinci sınıf Sosyal Bilgiler dersinde değer 
eğitiminin nasıl gerçekleştiğini (Çengelci, 2010); öğretmenlerin değer yönelimlerini (Gedik Güney, 2010); Sosyal Bilgiler Dersi Öğretim Programı'nda yer alan değerlerin kazandırılma sürecine ilişkin öğretmen görüşlerini (Kılıç-Şahin, 2010); öğretmenlerin değer öğretiminde kullandıkları yöntemleri (Akbaş, 2009); öğretmen adaylarının Sosyal Bilgiler Dersi Öğretim Programı'nda yer almasını öngördükleri değerler ve hangi değerlerin neden öğretileceğine dair görüşleri (Tay, 2009); sınıf öğretmenlerinin ve tarih öğretmenlerinin değer eğitimi hakkında görüşleri (Yıldırım, 2009; Tokdemir, 2007); Eğitim Fakültesi Sınıf Öğretmenliği ve Sosyal Bilgiler Öğretmenliği öğrencilerinin, değer öğretimi hakkındaki görüşlerini (Kurtdede Fidan, 2009); geleneksel ve demokratik değerlere yönelik öğrenci tutumlarını (Ulusoy, 2007); değer eğitimine yönelik genel açıklamaları içeren (Yazıcı, 2006) ve yeni ilköğretim Sosyal Bilgiler dersi programında insan hakları ve değer eğitiminin yer alış biçimini anlatan (Tezgel, 2006) tanıtıcı çalışmalar ile değer eğitimi kapsamında ele alınabilecek öğretmenlerin değer tercihleri (Sar1, 2005); Türk Milli Eğitim Sisteminin duyuşsal amaçlarının ilköğretim II. kademede gerçekleşme derecesinin değerlendirilmesi (Akbaş, 2004); ilköğretim Sosyal Bilgiler programında ulusal ve evrensel değerlerin yer alma sıklığını (Evin ve Kafadar, 2004) belirlemeye çalışan çalışmalar mevcuttur. Ders kitaplarında geçen değerlerin belirlenmesi, vatandaşlık eğitimiyle ilgili öğretmenlerin düşünceleri, Sosyal Bilgileri oluşturan farklı disiplinlerin değerlerle ilişkisi, değerlerin hangi yollarla kazandırılması gibi değerler eğitimi uygulamaları konularında birçok çalışmanın olduğu ancak etkili vatandaşlık eğitiminde değerler eğitimi ve öğretmen görüşlerinin alındığı bir çalışmaya (Demirhan-İşcan ve Demir, 2009; Hablemitoğlu ve Özmete, 2012; Sağlam, 2012; Karasu Avc1, 2016; Çevik Kansu, 2015; Kan, 2010; Kurtdede Fidan, 2009; Balcı ve Yanpar Yelken, 2010; Çelikkaya, Filoğlu ve Öktem, 2013; Ersoy ve Şahin, 2012; Yaşar ve Çengelci, 2012, Som ve Karataş, 2015, Faiz ve Yazıc1, 2018; Karasu Avc1 ve Faiz, 2018) doğrudan rastlanmamaktadır. Bu bağlamda etkili vatandaşlık eğitiminde değerler ve değerler eğitiminde öğretmen görüşlerinin tespit edilmesinin gereği ortaya çıkmaktadır. Bu doğrultuda araştırmanın problem cümlesi "Sosyal bilgiler öğretmenlerinin etkili vatandaşlık eğitiminde değerler ve değerler eğitimine yönelik düşünceleri nelerdir?" olarak belirlenmiştir. 


\section{Yöntem}

$\mathrm{Bu}$ araştırmada Sosyal Bilgiler öğretmenlerinin deneyimlerinden yola çıkılarak düşünceleri ele alındığı için nitel araştırma modellerinden olgubilim deseni tercih edilmiştir. Olgubilim, bağımsız katılımcıların deneyimlerinden oluşan olgunun detaylı tanımlandığı araştırma sorgulamaya dayalı bir yöntemdir (Creswell, 2012; Fraenkel ve Wallen, 2009).

\section{Çalışma Grubu}

$\mathrm{Bu}$ araştırmanın çalışma grubunu farklı yerlerde (köy, kasaba, ilçe, il) görev yapan 19 Sosyal Bilgiler öğretmeni oluşturmaktadır. Araştırmaya katılan öğretmenlerin farklı yerleşim birimlerinden seçilmesinin nedeni öğretmenlerin fark11 mekânlarda farklı tecrübeler geçirmeleridir. Bu bağlamda kolay ulaşılabilir örneklem türlerinden uygun örnekleme yönteminden faydalanılmıştır. Uygun örnekleme, araştırmacıya zaman, para, ulaşım vb. yönlerden kolaylık sağlayan ve araştırmaya o an için istekli ve uygun olan insanların seçildiği bir örnekleme çeşididir (Creswell, 2012; Marshall, 1996).

\begin{tabular}{|c|c|c|c|}
\hline Sira No & Cinsiyet & Mesleki Deneyim & Çalışılan Yer \\
\hline 1 & Erkek & $0-5$ Yil & İlç̧e \\
\hline 2 & Erkek & 16-20 Y11 & İlçe \\
\hline 3 & Kadın & $0-5$ Yil & İlçe \\
\hline 4 & Erkek & 6-10 Y11 & Köy \\
\hline 5 & Kadın & 6-10 Y1l & İlçe \\
\hline 6 & Erkek & 6-10 Y11 & İl \\
\hline 7 & Erkek & $11-15$ Y1l & İl \\
\hline 8 & Erkek & 11-15 Y11 & İl \\
\hline 9 & Kadın & 16-20 Y1l & Köy \\
\hline 10 & Erkek & $0-5$ Yil & İlçe \\
\hline 11 & Erkek & 6-10 Y11 & Kasaba \\
\hline 12 & Kadın & $0-5 Y_{11}$ & İl \\
\hline 13 & Erkek & 11-15 Y11 & Köy \\
\hline 14 & Erkek & $11-15$ Y1l & İl \\
\hline 15 & Erkek & 21 Yil ve Üstü & İl \\
\hline 16 & Erkek & 21 Yil ve Üstü & İl \\
\hline 17 & Kadın & $16-20 Y_{11}$ & İl \\
\hline 18 & Erkek & 21 Yil ve Üstü & İl \\
\hline 19 & Erkek & 21 Y1l ve Üstü & İl \\
\hline
\end{tabular}

Araştırmaya katılan öğretmenlerin 14'ü erkek, 5'i kadın olmak üzere toplam 19'dur. Öğretmenlerin mesleki deneyimleri incelendiğinde 4'ünün 0-5 yıl, 4'ünün 6-10 y1l, 4'ünün 11-15 yıl, 3'ünün 16-20 yıl, 4'ünün ise 21 yıl ve üstü 
görev yaptığı görülmektedir. Ayrıca öğretmenlerin 3'ü köyde, 1'i kasabada, 5'i ilçe merkezinde, 10 ’u ise il merkezinde görev yapmaktadır.

\section{Veri Toplama Araçları}

$\mathrm{Bu}$ araştırmada veriler görüşme formu yoluyla elde edilmiştir. Görüşme formu yapılandırılmış görüşme formu şeklinde tasarlanmıştır. Araştırmada Sosyal Bilgiler öğretmenlerine aşağıdaki sorular yöneltilmiştir:

1. Değerler ve vatandaşlık eğitimi arasında nasıl bir ilişki vardır? Açıklayınız.

2. Etkili bir vatandaşın sahip olduğu değerler nelerdir?

3. 2018 Sosyal Bilgiler Öğretim Programı'ndaki hangi değerler etkili vatandaşlık eğitimi için daha önemlidir?

4. Etkili vatandaşlık eğitimi için 2018 Sosyal Bilgiler Öğretim Programı'na eklenmesi gereken değerler var mıdır? Varsa bu değerler nelerdir? Yoksa neden olmadığını belirtiniz.

5. Etkili vatandaşlık eğitimi için değerler öğrencilere hangi yollar kullanılarak kazandırılmalıdır? Açıklayınız.

6. Etkili vatandaşlık eğitiminde değerlerin kazandırılması boyutunda Sosyal Bilgiler öğretmenlerinin rolleri nelerdir? Açıklayınız.

\section{Verilerin Analizi}

Elde edilen veriler NVIVO 11 programında betimsel analiz yoluyla çözümlenmiştir. Betimsel analiz, elde edilmiş olan bulguların okuyucuya özetlenmiş ve yorumlanmış bir biçimde sunulmasıdır. Elde edilen veriler daha önceden belirlenen çerçeveye göre düzenlenir (Yıldırım ve Şimşek, 2003).

\section{Araştırmanın Geçerliği ve Güvenirliği}

Nitel araştırmalarda geçerlik; araştırmacıların, katılımcıların ve okuyucuların verilerin analizi sonucu elde edilen bulgulardan aynı şeyi anlamaları ve aynı çıkarımda bulunmalarıdır (Creswell, 2012). Bu araştırmada ise geçerlik, elde edilen bulguların ayrıntılı bir şekilde açıklanması ve bulgulara ilişkin öğretmen adaylarının görüşlerine doğrudan yer verilmesi yoluyla sağlanmaya çalışılmıştır. Nitel araştırmalarda güvenirlik; elde edilen verilerin birden fazla kodlayıcı tarafından analiz edilmesi ve görüş ayrılığına düşülen durumlarda ortak bir ka- 
rara varılması olarak açıklanmaktadır (Creswell, 2012). Bu araştırmada araştırmacılar verilerin kodlanması, sınıflara ayrılması ve kategori geliştirme sürecinde yer almıştır. Görüşlerde meydana gelen farklılıklar araştırmacıların bir araya gelmesi ve ortak bir karara varmaları ile çözümlenmiştir. Patton (2014) nitel araştırmalarda güvenirliği sağlamak için yapılan bu işlemi analizci üçgenlemesi olarak açıklamaktadır. $\mathrm{Bu}$ araştırmada başlangıçta araştırmacılar kategorilere ve verilmek istenen kodlamalarda ihtilafa düşmüşlerdir. Ancak daha sonra bir araya gelerek ortak bir noktada birleşmişlerdir.

\section{Bulgular}

Araştırmanın bu bölümünde Sosyal Bilgiler öğretmenlerinin etkili vatandaşlık eğitiminde değerler ve değerler eğitimine yönelik düşüncelerine ait bulgular tablolar halinde sunulmaktadır. Öğretmenlerin sorulara verdiği cevaplara alt problemler halinde aşağıda verilmektedir.

\section{Birinci Alt Probleme İlişkin Bulgular}

Araştırmanın birinci alt problemi "Sosyal Bilgiler öğretmenlerine göre değerler ve vatandaşlık eğitimi arasında nasıl bir ilişki vardır?" şeklindedir. Bu alt probleme ilişkin öğretmenlerin düşünceleri Tablo 2'de verilmektedir:

\begin{tabular}{|c|c|c|c|c|}
\hline Tema & Doğrudan İlişkili & Birbirini Kapsayıcı & Birbirini Tamamlayıcı & Olumlu Etkileme \\
\hline$\%$ & 42,1 & 31,5 & 15,8 & 10,6 \\
\hline Ö1 & & & & $\sqrt{ }$ \\
\hline Ö2 & & $\sqrt{ }$ & & \\
\hline Ö3 & $\sqrt{ }$ & & & \\
\hline Ö4 & & $\sqrt{ }$ & & \\
\hline Ö5 & $\sqrt{ }$ & & & \\
\hline Ö6 & $\sqrt{ }$ & & & \\
\hline Ö7 & 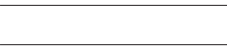 & & & $\sqrt{ }$ \\
\hline Ö8 & & & $\sqrt{ }$ & \\
\hline Ö9 & $\sqrt{ }$ & & & \\
\hline Ö10 & $\sqrt{ }$ & & & \\
\hline Ö11 & & & $\sqrt{ }$ & \\
\hline Ö12 & & $\sqrt{ }$ & & \\
\hline Ö13 & & $\sqrt{ }$ & & \\
\hline Ö14 & & $\sqrt{ }$ & & \\
\hline Ö15 & & $\sqrt{ }$ & & \\
\hline Ö16 & $\sqrt{ }$ & & & \\
\hline Ö17 & $\sqrt{ }$ & & & \\
\hline Ö18 & $\sqrt{ }$ & & & \\
\hline Ö19 & & & $\sqrt{ }$ & \\
\hline
\end{tabular}


Tablo 2 incelendiğinde öğretmenlerin bu alt probleme ait düşünceleri 4 tema altında toplanmıştır. Bu temalar "birbiri ile doğrudan ilişkili, birbirini kapsayıcı, birbirini tamamlayıcı ve birbirini olumlu etkileme özelliğine sahip" şeklindedir. Öğretmenler \%42,1 ile en fazla "birbiri ile doğrudan ilişkili" temasına ilişkin düşüncelerini belirtmişlerdir. Bu temayı $\% 31,5$ ile "birbirini kapsayıcı"; \%15,7 ile "birbirini tamamlayıcı" ve \% 10,5 ile de "birbirini olumlu etkileme özelliğine sahip" temaları izlemektedir.

"Birbiri ile doğrudan ilişkili” teması ile ilgili öğretmenlerden bazılarına ait görüşler şu şekildedir:

"Doğrudan ilişki vardır. Değerlerine sahip olan birey iyi bir insan olur. (Ö17)", "Değerler toplumda birlik ve beraberliği sağlayan unsurlardır. Vatandaşlık eğitiminde amaç kendi hakkını, hukukunu bilen, aynı zamanda başkalarının hakkını gözeten, eleştiren, sorgulayan bireyler yetiştirmektir. Vatandaşlık eğitiminde bu çerçeve içerisinde yetişen bireyler değerlere sahip olmuş olacaktır. Bu nedenle doğrudan ilişsilidir. (Ö18)"

Ö17 kodlu öğretmen değerlere sahip olan bireyin aynı zamanda etkili vatandaş olacağını da düşünmekte iken Ö18 kodlu öğretmen değerlerin vatandaşl1k eğitiminin bir parçası olduğunu dile getirmektedir. Dolayısıyla her iki öğretmende değerleri doğrudan etkili vatandaşlık ile ilişkilendirmektedir.

"Birbirini kapsayıcı teması" ile ilgili öğretmenlerden bazılarına ait görüşler şu şekildedir:

"Yakın ve kapsayıcı. (Ö4)", "Vatandaşlık eğitimi değerleri içinde barındırmaktadır. Adalet, vatanseverlik gibi değerler vatandaşlık eğitiminin temel konularını oluşturmaktadır. (Ö12)"

Ö4 kodlu öğretmen değerler ve etkili vatandaşlığın birbirini kapsayıcı olduğunu ifade ederken Ö12 kodlu öğretmen ise bazı değerlerin vatandaşlık eğitiminin temel konuları olduğunu belirtmektedir.

"Birbirini tamamlayıcı" teması ile ilgili öğretmenlerden bazılarına ait görüşler şu şekildedir:

"Birbirinin tamamlayıcısıdır. (Ö8)", "Birbirini tamamlıyor değer olmadan vatandaşlık eksik kalır. (Ö11)", "Programdaki değerler vatandaş olmanın gereklerindendir. Vatandaşlık eğitiminin temelini değerler oluşturmalıdır. (Ö19)" şeklinde ifade etmişlerdir.

Ö8 ve Ö11 değerlerin etkili vatandaşlık eğitiminin tamamlayıcısı olduğunu belirtirken Ö19 ise vatandaşlık eğitiminin temelinde değerlerin bulunduğunu ifade etmiştir. 
"Birbirini olumlu etkileme" özelliğine sahip teması ile ilgili öğretmenlerden bazılarına ait görüşler şu şekildedir:

"Vatandaşlık başlı başına soyut ve anlam yönü ile güçlü bir kazanımdır. Değerler eğitiminin öğrenciye aktarımı vatandaşlık bağının oluşumunu da olumlu etkiler. (Ö1)" "Değerler eğitimi iyi bir vatandaş olma yolunda etkilidir. (Ö7)"

Ö1 ve Ö7 kodlu öğretmenler değerlerin bireyin iyi vatandaş olmasını olumlu yönde etkilediğini belirtmektedirler. Dolayısıyla da değerler ve iyi vatandaşlık arasında birbirini etkileme bakımından olumlu bir özellik olduğu söylenebilir.

\section{İkinci Alt Probleme İlişkin Bulgular}

Araştırmanın ikinci alt problemi "Sosyal Bilgiler öğretmenlerine göre etkili bir vatandaşın sahip olduğu değerler nelerdir?" şeklindedir. Bu alt probleme ilişkin öğretmenlerin düşünceleri Tablo 3’te verilmektedir.

Tablo 3: Öğretmenlere Göre Etkili Vatandaşın Sahip Olduğu Değerler

\begin{tabular}{|c|c|c|c|c|c|c|c|c|c|c|c|c|c|c|c|c|}
\hline 艻 & 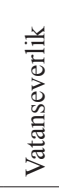 & 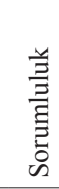 & 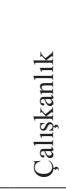 & 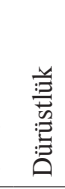 & $\frac{\vec{s}}{\frac{g}{4}}$ & 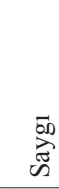 & 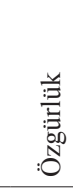 & 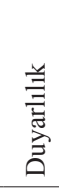 & 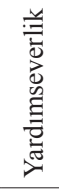 & 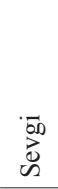 & 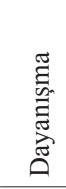 & 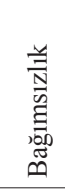 & 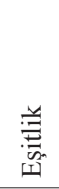 & 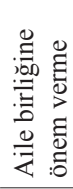 & 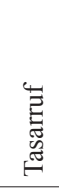 & $\begin{array}{l}\text { 羔 } \\
\text { 禀 }\end{array}$ \\
\hline$\%$ & $\stackrel{\circ}{\stackrel{0}{=}}$ & 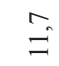 & $\hat{=}$ & $\stackrel{\overbrace{}}{\varrho}$ & $\stackrel{\infty}{\infty}$ & $\begin{array}{c}\infty \\
i\end{array}$ & $\stackrel{+}{+}$ & $\stackrel{+}{+}$ & ते & $\begin{array}{l}\infty \\
\dot{n}\end{array}$ & ते & iे & $\begin{array}{l}\infty \\
\text { in }\end{array}$ & $\vec{i}$ & ते & $\stackrel{\Xi}{=}$ \\
\hline Ö1 & $\sqrt{ }$ & $\sqrt{ }$ & $\sqrt{ }$ & $\sqrt{ }$ & & & & & & & & & & & & \\
\hline Ö2 & $\sqrt{ }$ & & & & $\sqrt{ }$ & & & & & & & & & & & \\
\hline Ö3 & & & $\sqrt{ }$ & $\sqrt{ }$ & & & & & & & & $\sqrt{ }$ & & & & \\
\hline Ö4 & $\sqrt{ }$ & & $\sqrt{ }$ & & & & & & & & & & & & & \\
\hline Ö5 & $\sqrt{ }$ & & & & & & & & & & & & & & & \\
\hline Ö6 & & $\sqrt{ }$ & $\sqrt{ }$ & $\sqrt{ }$ & & & & & & & & & & & & \\
\hline Ö7 & & & & & & & & & & & & & & & & \\
\hline Ö8 & & $\sqrt{ }$ & & $\sqrt{ }$ & & & & & & & & & & & & \\
\hline Ö9 & $\sqrt{ }$ & $\sqrt{ }$ & $\sqrt{ }$ & $\sqrt{ }$ & $\sqrt{ }$ & & & & & & & & & & & \\
\hline Ö10 & $\sqrt{ }$ & & & & & & $\sqrt{ }$ & & & & & & & & & \\
\hline Ö11 & $\sqrt{ }$ & $\sqrt{ }$ & & & & & & & & & & & $\sqrt{ }$ & & & \\
\hline Ö12 & $\sqrt{ }$ & $\sqrt{ }$ & & & & & & & & & & & & & & \\
\hline Ö13 & $\sqrt{ }$ & $\sqrt{ }$ & $\sqrt{ }$ & & $\sqrt{ }$ & $\sqrt{ }$ & $\sqrt{ }$ & $\sqrt{ }$ & $\sqrt{ }$ & $\sqrt{ }$ & $\sqrt{ }$ & & $\sqrt{ }$ & $\sqrt{ }$ & $\sqrt{ }$ & \\
\hline Ö14 & & & & & & $\sqrt{ }$ & & & & $\sqrt{ }$ & & & $\sqrt{ }$ & & & \\
\hline Ö15 & $\sqrt{ }$ & $\sqrt{ }$ & $\sqrt{ }$ & $\sqrt{ }$ & $\sqrt{ }$ & $\sqrt{ }$ & $\sqrt{ }$ & $\sqrt{ }$ & $\sqrt{ }$ & $V$ & $\sqrt{ }$ & $\sqrt{ }$ & & & & $\sqrt{ }$ \\
\hline Ö16 & & & & & & & & & & $\sqrt{ }$ & & & $\sqrt{ }$ & $\sqrt{ }$ & $\sqrt{ }$ & \\
\hline Ö17 & $\sqrt{ }$ & & & & & & & & & & & & & & & \\
\hline Ö18 & & & & & & & & $\sqrt{ }$ & & & & & & & & \\
\hline Ö19 & $\sqrt{ }$ & & $\sqrt{ }$ & $\sqrt{ }$ & & $\sqrt{ }$ & & & & & & & & & & \\
\hline
\end{tabular}


Araştırmanın bu sorusunda öğretmenler etkili bir vatandaşın sahip olduğu değerlere ilişkin birden fazla değer belirtmişlerdir. Öğretmenlere göre etkili bir vatandaşın sahip olması gereken en önemli değerler sırasıyla \%17,6 ile "vatanseverlik"; \%11,7 ile "sorumluluk" ve "çalışkanlık" ve \%10,2 ile "dürüstlük" değerleridir. Bu değerleri \%5,8 ile "adalet" ve "saygı"; \%4,4 ile "özgürlük" ve "duyarlık"; \%2,9 ile "yardımseverlik", "sevgi", "dayanışma", "bağımsızl1k", "eşitlik", "aile birliğine önem verme" ve "tasarruf"; \%1,4 ile "bilimsellik" değeri izlemektedir. 2018 Sosyal Bilgiler Öğretim Programı'nda yer alan 18 değerden 16'sını öğretmenlerin etkili vatandaşlık için gerekli olan değer olarak belirttiği görülmektedir. Öğretmelerden bazılarının araştırmanın bu sorusuna ilişkin düşünceleri aşağıda verilmektedir:

"Çalışkanlık, dürüstlük, vatan sevgisi, sorumluluk nedeni ülkeye vatandaşlık bağının bu değerleri gerektirmesi. (Ö1)", "Vatanseverlik, çalışkanlık çünkü bunlar olmadan vatandaşlık eğitimi olmaz. (Ö3)", "Vatansever, sorumluluk sahibi, dürüst, duyarlı, çalışkan, adil olmalı. Çünkü insan önce vatanını sevmeli ve sevgisini sorumluluklarını yerine getirerek göstermeli. Duyarlı ve çalışkan olmadan da etkili vatandaş olunamaz. (Ö9)”, “...sorumluluk, çünkü vatanseverlik vatan için sorumluluk getirir. (Ö12)”,"Her şeyden önce saygı ve sevgi olmalıdır. Çünkü insanların birbirine saygı ve sevgisinin olduğu durumlarda insanlar diğer değerleri daha kolay benimseyecek ve uygulayacaklardır. (Ö14)"

Öğretmenler etkili vatandaşlık için kendilerine göre en önemli değerleri belirtmişlerdir. Ö1, Ö2, Ö9, Ö12 ve Ö14 belirttikleri değerlerin vatandaşl1k eğitiminde en önemli değerler olduğunu düşünmektedirler. Dolayısıyla etkili vatandaşlık niteliğine sahip bireylerin de bu değerleri taşıyan bireyler olduğu söylenebilir.

\section{Üçüncü Alt Probleme İlişkin Bulgular}

Araştırmanın üçüncü alt problemi "Sosyal Bilgiler öğretmenlerine göre Sosyal Bilgiler Öğretim Programı'ndaki hangi değerler etkili vatandaşlık eğitimi için daha önemlidir?” şeklindedir. Bu alt probleme ilişkin öğretmenlerin düşünceleri Tablo 4'te verilmektedir: 


\begin{tabular}{|c|c|c|c|c|c|c|c|c|c|c|c|c|c|c|c|}
\hline 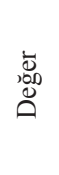 & 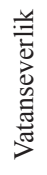 & 象 & 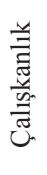 & 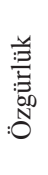 & 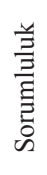 & $\frac{\overrightarrow{0}}{\frac{\pi}{\pi}}$ & $\begin{array}{l}\overrightarrow{50} \\
\stackrel{\vec{A}}{\vec{D}}\end{array}$ & 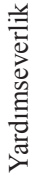 & 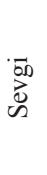 & 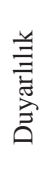 & 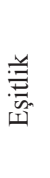 & 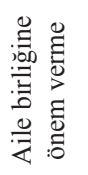 & 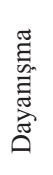 & 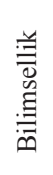 & 意 \\
\hline$\%$ & $\stackrel{2}{a}$ & $\cong$ & $\stackrel{0}{a}$ & $\stackrel{0}{0}$ & $\stackrel{0}{\circ}$ & $\stackrel{0}{\sim}$ & in & $\hat{n}$ & $\stackrel{\infty}{\infty}$ & $\stackrel{\infty}{\infty}$ & $\stackrel{\infty}{\infty}$ & $\stackrel{\infty}{\boldsymbol{m}^{n}}$ & $\stackrel{و}{\Rightarrow}$ & $\Rightarrow$ & $\stackrel{9}{-}$ \\
\hline Ö1 & $\sqrt{ }$ & & & & $\sqrt{ }$ & & & & & $\sqrt{ }$ & & & & & \\
\hline Ö2 & & & $\sqrt{ }$ & $\sqrt{ }$ & & & & & & & & & & & \\
\hline Ö3 & & $\sqrt{ }$ & $\sqrt{ }$ & & & $\sqrt{ }$ & & & & & & & & & \\
\hline Ö4 & & & $\sqrt{ }$ & $\sqrt{ }$ & & & & & & & & & & & \\
\hline Ö5 & $\sqrt{ }$ & & $\sqrt{ }$ & & & & & & & & & & & & \\
\hline Ö6 & $\sqrt{ }$ & $\sqrt{ }$ & $\sqrt{ }$ & & $\sqrt{ }$ & & & & & & & & & & \\
\hline Ö7 & & & & & & & & $\sqrt{ }$ & & & & & & & \\
\hline Ö8 & & $\sqrt{ }$ & & & $\sqrt{ }$ & & & $\sqrt{ }$ & & & & & & & \\
\hline Ö9 & $\sqrt{ }$ & & & & & & & & & & & & & & \\
\hline Ö10 & $\sqrt{ }$ & & & $\sqrt{ }$ & & & & & & & & & & & \\
\hline Ö11 & $\sqrt{ }$ & & & & & $\sqrt{ }$ & & & & & & & & & \\
\hline Ö12 & & & & & $\sqrt{ }$ & & & & & & & & & & \\
\hline Ö13 & $\sqrt{ }$ & $\sqrt{ }$ & & & $\sqrt{ }$ & & & & & $\sqrt{ }$ & & $\sqrt{ }$ & & & \\
\hline Ö14 & & & & & & & $\sqrt{ }$ & $\sqrt{ }$ & $\sqrt{ }$ & & & & & & \\
\hline Ö15 & & & & & & & & & $\sqrt{ }$ & & & & & & \\
\hline Ö16 & $\sqrt{ }$ & $\sqrt{ }$ & & $\sqrt{ }$ & & $\sqrt{ }$ & $\sqrt{ }$ & & & & $\sqrt{ }$ & & & & \\
\hline Ö17 & $\sqrt{ }$ & $\sqrt{ }$ & $\sqrt{ }$ & $\sqrt{ }$ & & $\sqrt{ }$ & $\sqrt{ }$ & & & & $\sqrt{ }$ & $\sqrt{ }$ & $\sqrt{ }$ & $\sqrt{ }$ & $\sqrt{ }$ \\
\hline \multicolumn{16}{|l|}{ Ö18 } \\
\hline Ö19 & $\sqrt{ }$ & & & & & & & & & & & & & & \\
\hline
\end{tabular}

Öğretmenlere göre Sosyal Bilgiler Öğretim Programı'nda etkili vatandaşlık eğitimi için önemli olan değerlere ilişkin 15 farklı değer belirtmişlerdir. Bu değerler en fazla sırasıly \%19,2 ile "vatanseverlik"; \%11,5 ile "dürüstlük"; \%9,6 ile "çalışkanlık", "özgürlük" ve "sorumluluk" şeklinde sıralanmaktadır. Bu değerleri \%7,6 ile "adalet"; \%5,7 ile "saygı" ve "yardımseverlik"; \%3,8 ile "sevgi", "duyarlılık", "eşitlik" ve "aile birliğine önem verme"; \%1,9 ile "dayanışma", "bilimsellik" ve "barış" değerleri izlemektedir. Öğretmelerden bazılarının araştırmanın bu sorusuna ilişkin düşünceleri aşağıda verilmektedir:

"Vatan sevgisi, duyarlılık ve sorumluluk alma. Vatandaşlık bağını olumlu anlamda desteklemesi. (Ö1)”, “Adalet, özgürlük ve çalışkanlık. (Ö4)”, "Dürüstlük. Bu değer olmadan da etkin ve başarılı olunamaz. (Ö6)”, “...Sorumluluk, çünkü vatandaşlık görevlerinin yerine getirilmesi sorumluluk almayı gerektirir. (Ö12)”, “Özgürlük, eşitlik, dürüstlük, hoşgörü, saygı, sevgi ve vatanseverlik 
gibi değerler her zaman sosyal bilgiler dersi için olmazsa olmaz denilen değerlerdir. (Ö16)"

Öğretmenlerin Sosyal Bilgiler Öğretim Programı'nda yer alan değerlere yönelik farklı görüşler belirttikleri söylenebilir. Ö1 kodlu öğretmen vatanseverlik, Ö4 kodlu öğretmen adalet, Ö6 kodlu öğretmen dürüstlük, Ö12 kodlu öğretmen sorumluluk ve Ö16 kodlu öğretmen özgürlük değerini belirtmiştir. Bu değerler dişında öğretmenlerin farklı değerleri de belirttikleri görülmektedir. Buna göre öğretmenlerin programda yer alan değerleri etkili vatandaşlık anlamında önemli buldukları anlaşılmaktadır.

\section{Dördüncü Alt Probleme İlişkin Bulgular}

Araştırmanın dördüncü alt problemi "Sosyal Bilgiler öğretmenlerine göre etkili vatandaşlık eğitimi için Sosyal Bilgiler Öğretim Programı’na eklenmesi gereken değerler var mıdır?” şeklindedir. Bu alt probleme ilişkin öğretmenlerin düşünceleri Tablo 5 'te verilmektedir:

Tablo 5: Etkili Vatandaşlık Eğitimi İçin Sosyal Bilgiler Öğretim Programı’na Eklenmesi Gereken Değerlere İlişkin Öğretmen Görüşleri

\begin{tabular}{|c|c|c|}
\hline Tema & Programdaki değerler yeterlidir & Eklenmesi gereken değerler vardır \\
\hline$\%$ & 68,4 & 31,5 \\
\hline Ö1 & $\sqrt{ }$ & \\
\hline Ö2 & $\sqrt{ }$ & \\
\hline Ö3 & $\sqrt{ }$ & \\
\hline Ö4 & $\sqrt{ }$ & \\
\hline Ö5 & $\sqrt{ }$ & \\
\hline Ö6 & $\sqrt{ }$ & \\
\hline Ö7 & $\sqrt{ }$ & \\
\hline Ö8 & & $\sqrt{ }$ \\
\hline Ö9 & & $\sqrt{ }$ \\
\hline Ö10 & $\sqrt{ }$ & \\
\hline Ö11 & & $\sqrt{ }$ \\
\hline Ö12 & $\sqrt{ }$ & \\
\hline Ö13 & & $\sqrt{ }$ \\
\hline Ö14 & & $\sqrt{ }$ \\
\hline Ö15 & $\sqrt{ }$ & \\
\hline Ö16 & $\sqrt{ }$ & \\
\hline Ö17 & & $\sqrt{ }$ \\
\hline Ö18 & $\sqrt{ }$ & \\
\hline Ö19 & $\sqrt{ }$ & \\
\hline
\end{tabular}


Araştırmanın bu alt problemine ilişkin öğretmenlerin düşünceleri 2 tema altında toplanmıştır. Tablo 5 'te görüldüğü gibi öğretmenler "programdaki değerler yeterlidir" ve "eklenmesi gereken değerler vardır" şeklinde düşüncelerini belirtmişlerdir. Öğretmenlerin \%68,4'ü programdaki değerlerin yeterli olduğunu düşünürken, \%31,5'i de eklenmesi gereken değerler bulunduğunu düşünmektedirler. Programdaki değerlerin yeterli olduğunu düşünen öğretmenler bu değerleri kazanan öğrencilerin gelecekte etkin bir vatandaş olacağını düşünmektedirler. Programa eklenmesi gereken yeni değerler olduğunu düşünen öğretmenler ise bu eklenmesiyle birlikte etkili vatandaşlık eğitimine katkı sağlanabileceğini belirtmektedirler. Öğretmelerden bazılarının araştırmanın bu sorusuna ilişkin düşünceleri aşağıda verilmektedir.

"Programdaki değerler yeterlidir" teması ile ilgili öğretmenlerden bazılarına ait görüşler şu şekildedir:

"Gerekli kazanımlar vardır önemli olan kazanımı daha güzel aktarmak. (Ö1)", "Gerekli değerler belirlenmiş önemli olan bunları öğrencilere doğru bir şekilde aktarabilmektir. (Ö6)", "Yeni bir değerden çok, eldeki değerleri öğrencilerimize iyi vermemiz gerekir. (Ö15)"

Ö1, Ö6 ve Ö15 kodlu öğretmenler programda var olan değerlerin etkili vatandaşlık eğitimi için yeterli olduğunu ancak önemli olan konunun bu değerlerin etkili bir şekilde kazandırılması olduğunu vurgulamaktadırlar.

"Eklenmesi gereken değerler vardır" teması ile ilgili öğretmenlerden bazılarına ait görüşler şu şekildedir:

"Öğretmene sayg1... (Ö8)", "Hoşgörü ve merhamet olabilir. (Ö9)”, "Milliyetçilik eklenebilir.(Ö11)", "Empati kurabilme, çevre bilinci ve çevreye uyum eklenebilir.(Ö14)"

Öğretim programına etkili vatandaşlık için eklenmesi gereken değerler olduğunu düşünen Ö8 kodlu öğretmen öğretmene sayg1 değerinin eklenmesini gerektiğini belirtmiştir. Ancak saygı değeri zaten programda yer alan bir değerdir. Ö9 kodlu öğretmenin belirttiği değerler programda yer almamaktadır. Ö11 kodlu öğretmen milliyetçiliğin bir değer olarak eklenmesini belirtmiştir. Bu kavramın bir değer olup olmadığı üzerine tartışılabilir. Vatanseverlik değeri kapsamında da bu kavram kazandırılabilir. Ö14 kodlu öğretmen ise empati ve çevre bilinci değerlerinin yer alması gerektiğini belirtmiştir. Programda empati 
ve çevre okuryazarlığg beceri olarak geçmektedir. Dolayısıyla programa eklenmesi gereken değerlerin hoşgörü, merhamet gibi programda bulunmayan değerler olabileceği söylenebilir.

\section{Beşinci Alt Probleme İlişkin Bulgular}

Araştırmanın beşinci alt problemi "Sosyal Bilgiler öğretmenlerine göre etkili vatandaşlık eğitimi için değerler öğrencilere hangi yollar kullanılarak kazandırılmalıdır?" şeklindedir. Bu alt probleme ilişkin öğretmenlerin düşünceleri Tablo 6'da verilmektedir:

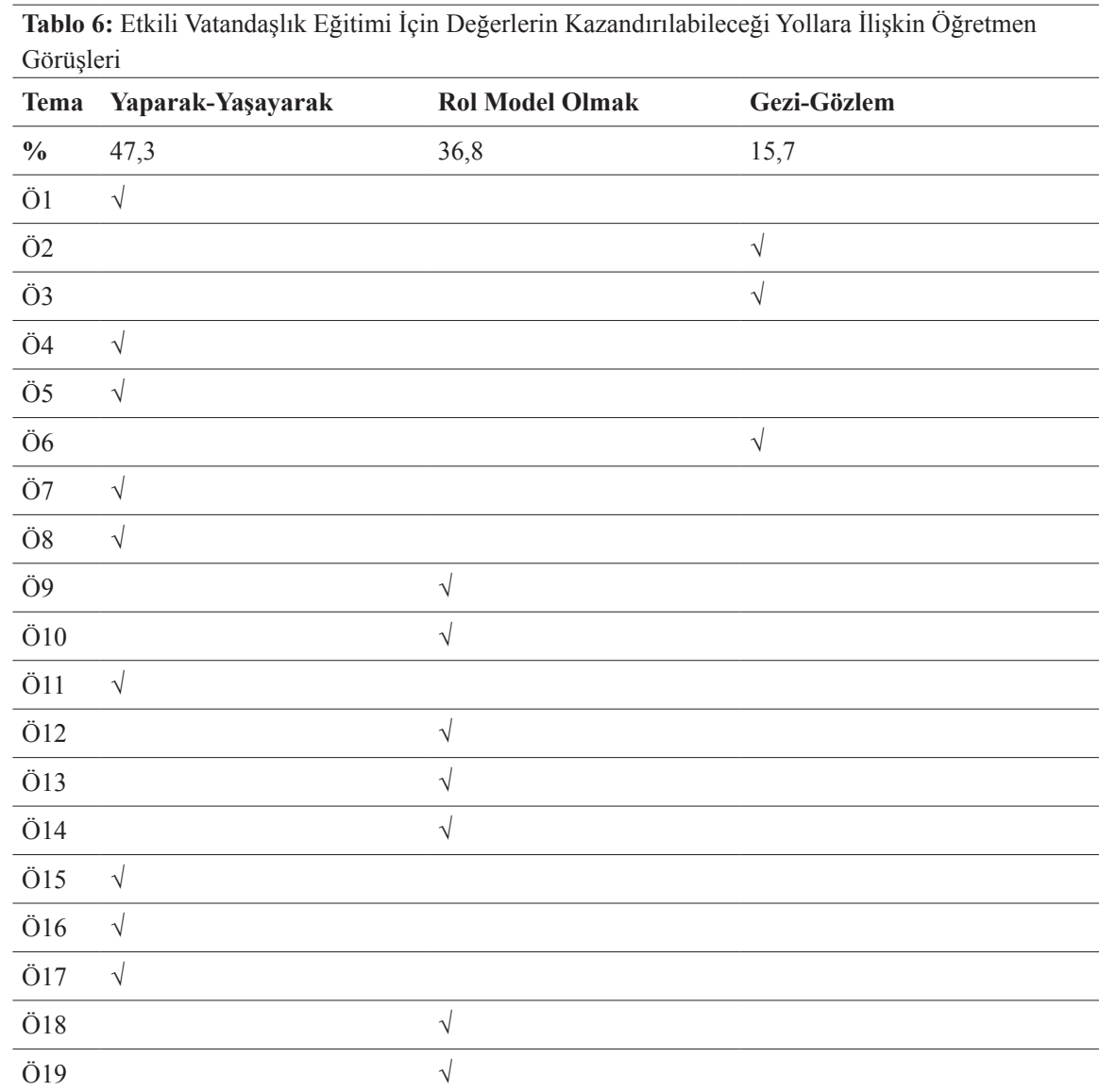

Öğretmenlerin bu alt problem çerçevesindeki ifadeleri 4 tema altında toplanmıştır. Bu temalar "yaparak-yaşayarak", "rol model olmak" ve "gezi-gözlem" şeklindedir. Öğretmenler en fazla sırasıyla \%47,3 ile "yaparak-yaşayarak", \%36,8 ile "rol model olmak" ve \%15,7 ile de "gezi-gözlem" yoluyla değerlerin kazandırılabileceğini belirtmişlerdir. Öğretmelerden bazılarının araştırmanın bu 
sorusuna ilişkin düşünceleri aşağıda verilmektedir.

"Yaparak-yaşayarak" teması ile ilgili öğretmenlerden bazılarına ait görüşler şu şekildedir:

"Yaparak yaşayarak ve örnek davranışların öğretmen tarafından sergilenmesi ile kalıcı öğretimin gerçekleşmesi daha başarılı olur. (Ö1)", "Yaparak yaşayarak öğretilmeli. (Ö11)", "Günlük hayatın içinden örnekler vererek, yaparak ve yaşatarak kazandırılmalıdır. (Ö17)”

Ö1, Ö11 ve Ö17 kodlu öğretmenler öğrenciler için yaparak-yaşayarak öğretimin kalıcı olduğundan ve öğrencilerin gerçek hayat örneklerinden yola çıkarak deneyim kazanacaklarını belirtmektedirler.

"Rol model olmak" teması ile ilgili öğretmenlerden bazılarına ait görüşler şu şekildedir:

"Öğrencilerin değerleri kazanmasında öğretmenlerin rol model olması önem arz etmektedir. (Ö13)", "Öğretmenler hatasız davranmalı. Örnek insanlar olmalı. Davranışlarıyla estetik duruşuyla kıyafetiyle vs. Yani her yönüyle hissettirmeli. Zaten öğrenci bizi taklit edecektir. Kitap okuma yarışmaları ile bu işler olmaz, nasihat etmekle olmaz. (Ö19)"

Ö13 ve Ö19 kodlu öğretmenler öğretmenin rol model olmasına değinmektedirler. Öğretmenlerin her yönüyle davranışlarına, söylemlerine, kılık kıyafetlerine dikkat etmelerini belirtmektedirler.

"Gezi-gözlem" teması ile ilgili öğretmenlerden bazılarına ait görüşler şu şekildedir: "Gezi gözlem, çünkü insan gezerek daha iyi öğrenir. (Ö3)", "Değerler, beceriler ve diğer öğrencinin kazanmasını istediğimiz her şey öğrencilere gezdirilerek, aktiviteler yaptırllarak verilmelidir. (Ö6)"

Ö3 ve Ö6 kodlu öğretmenler gezi gözlem yoluyla değerlerin daha iyi öğrenildiğini belirterek aktivite yaptırmanın önemine dikkat çekmektedirler.

\section{Altıncı Alt Probleme İlişkin Bulgular}

Araştırmanın altıncı alt problemi "Sosyal Bilgiler öğretmenlerine göre etkili vatandaşlık eğitiminde değerlerin kazandırılması boyutunda Sosyal Bilgiler öğretmenlerinin rolleri nelerdir?" şeklindedir. Bu alt probleme ilişkin öğretmenlerin düşünceleri Tablo 7'de verilmektedir: 
Tablo 7: Etkili Vatandaşlık Eğitiminde Değerlerin Kazandırılması Boyutunda Sosyal Bilgiler Öğretmenlerinin Rollerine İlişkin Öğretmen Görüşleri

\begin{tabular}{llll}
\hline Tema & Rol Model Olmak & Yol Gösteren Olmak & Özverili Olmak \\
\hline \% & 78,9 & 15,7 & 5,2 \\
\hline Ö1 & $\sqrt{ }$ & $\sqrt{ }$ & \\
\hline Ö2 & & $\sqrt{ }$ & \\
\hline Ö3 & & & $\sqrt{ }$ \\
\hline Ö4 & $\sqrt{ }$ & & \\
\hline Ö5 & & $\sqrt{ }$ & \\
\hline Ö6 & $\sqrt{ }$ & \\
\hline Ö7 & & & \\
\hline Ö8 & $\sqrt{ }$ & \\
\hline Ö9 & $\sqrt{ }$ & \\
\hline Ö10 & $\sqrt{ }$ & \\
\hline Ö11 & $\sqrt{ }$ & \\
\hline Ö12 & $\sqrt{ }$ & \\
\hline Ö13 & $\sqrt{ }$ & \\
\hline Ö14 & $\sqrt{ }$ & \\
\hline Ö15 & $\sqrt{ }$ & \\
\hline Ö16 & $\sqrt{ }$ & \\
\hline Ö17 & $\sqrt{ }$ & \\
\hline Ö18 & $\sqrt{ }$ & \\
\hline Ö19 & $\sqrt{ }$ & \\
\hline
\end{tabular}

Öğretmenlerin düşünceleri bu alt problemde 3 tema altında toplanmıştır. Öğ retmenler kendi rollerine ilişkin düşüncelerini sırasıyla \%78,9 ile "rol model olmak", \%15,7 "yol gösteren olmak" ve \%5,2 ile "özverili olmak” olarak belirtmişlerdir. Buna göre öğretmenlerin çoğunluğunun etkili vatandaş eğitiminde rol model olmanın önemli olduğunu düşündükleri görülmektedir. Öğretmenlerden bazılarının araştırmanın bu sorusuna ilişkin düşünceleri aşağıda verilmektedir.

"Rol model olmak" teması ile ilgili öğretmenlerden bazılarına ait görüşler şu şekildedir:

"Bizler çocuk için rol modeliz. (Ö8)", "Rol model olmamız gerekir. (Ö14)", "Öğretmen mutlaka örnek kimliği ile öğrencilere rol model olmalıdır. Özellikle paylaşımcılık, saygı, sevgi, hoşgörü, eşitlik, vatan ve millet sevgisi noktasında... (Ö16)" 
Ö8 ve Ö9 kodlu öğretmenler etkili vatandaşlık eğitiminde değerlerin kazandırılması boyutunda öğretmenlerin rol model olmaları üzerinde dururken Ö16 kodlu öğretmen ise öğretmenlerin hangi konularda rol model olabileceklerini de belirtmiştir.

"Yol gösteren olmak" teması ile ilgili öğretmenlerden bazılarına ait görüşler şu şekildedir:

"Yol gösterici olmalıdır. (Ö3)”, "Öğretmen yol gösteren olmalı yapılacak etkinliklerle etkin vatandaş bilinci uyandırmalı öğrencide. (Ö7)", "Branş olarak ayırt etmek istemem. Her öğretmen aynı öneme sahiptir, yol göstermelidir. (Ö19)"

Ö3, Ö7 ve Ö19 kodlu öğretmenler etkili vatandaşl1k eğitiminde değerlerin kazandırılması boyutunda öğretmenlerin yol gösterici olmalarını belirtirken Ö7 kodlu öğretmen, öğretmenlerin etkili vatandaş olma bilinci uyandırması noktasında yol gösterici olması gerektiğine dikkat çekmektedir.

"Özverili olmak" teması ile ilgili öğretmenlerden bazılarına ait görüşler şu şekildedir:

"Öğretmen özverili olmalıdır. (Ö5)"

Bu temaya ilişkin sadece Ö5 kodlu öğretmen görüş belirtmiştir. Bu öğretmenin sadece öğretmenin özveri olması gerektiğine dikkat çektiği ancak bu özverinin ne olabileceğini açıkça belirtmediği anlaşılmaktadır.

\section{Tartışma, Sonuç ve Öneriler}

Sosyal Bilgiler öğretmenleri vatandaşlık eğitimi ve değerler arasındaki ilişkiyi birbiri ile doğrudan ilişkili, birbirini kapsayıcı, birbirini tamamlayıcı ve birbirini olumlu etkileme özelliğine sahip olarak açılamaktadırlar. Demirhan-İşcan ve Demir (2009) çalışmalarında vatandaşlık eğitiminde vatandaşlık hak, sorumluluk ve görevlerinin yerine getirilmesinde değerlerle olan ilişkisine değinmektedirler. Merey, Kuş ve Karatekin (2012a) Türkiye'de vatandaşl1k eğitiminin bireysel ve toplumsal değerler yoluyla kazandırılmaya çalışıldığını belirtmektedirler. Kızılay (2015)'ın çalışmasında da öğrenciler iyi vatandaşın özelliklerini belirtirken en fazla değer boyutuna vurgu yapmışlardır. Nzahabwanayo (2016)'nın çalışmasında vatandaşlığın kazanılmasında değerlerin hem milli hem de uluslararası düzeyde etkili ve önemli olduğundan bahsedilmektedir. Sim ve Low (2012)'a göre değerler eğitimi yoluyla öğrencilere sevgi, sayg1 gibi temel ahlaki değerlerin kazandırılmasının öğrencilerin topluma uyum sağ- 
lamasında ve demokrasinin toplumsal hayata yerleştirilmesinde önemli olduğu vurgulanmaktadır. Turnbull (2002) da vatandaşlık eğitiminde değerlerin kültürel devamlılık sağlamadaki rolüne değinmektedir. Özellikle farklı kültürlerdeki bireylerden oluşan toplumların genel bir çerçevede birleştirilebilmesinde ortak değerlerin bireylere kazandırılması önemlidir.

Öğretmenler etkili bir vatandaşın sahip olması gereken en önemli değerleri vatanseverlik, sorumluluk, çalışkanlık, dürüstlük, adalet, saygı, özgürlük ve duyarlılık olarak düşünmektedirler. Öğretmenlerin etkili vatandaşlık eğitimi için belirttikleri değerlerden 16'sı 2018 SBÖP programında yer alan değerlerdir. 2018 SBÖP'nda etkili vatandaşlık eğitimi için önemli olan değerler ise öğretmenlere göre vatanseverlik, dürüstlük, çalışkanlık, özgürlük ve sorumluluktur. Merey vd. (2012a) Türkiye'de Sosyal Bilgiler dersi ile vatandaşlık eğitiminin bireysel ve toplumsal değerler yoluyla kazandırılmaya çalışıldığını belirtirler. Kan (2009b) çalışmasında vatandaş kavramını sorumluluk değeriyle açıklamaktadır. Bu durum vatandaşlık için önemli olan değerlerden birisi sorumluluk değeri olduğunu ortaya koyması bakımından önemlidir. Kan (2009a) bir başka çalışmasında da vatandaşlı̆̆ın bazı değerlere sahip olmakla ilişkili olduğundan bu değerlerin ise ulusal ve evrensel değerler olduğundan bahsetmektedir. Sim ve Low (2012) da vatandaşlık eğitimi için sevgi, saygı gibi temel değerlerin kazandırılmasının gereğinden bahsetmektedir. Deer (2008) çalışmasında Kanada vatandaşlığının kazandırılması için Sosyal Bilgiler dersinde eşitlik, kültürel farklılıklara saygı, özgürlük, barış, hukuk ve düzen değerlerinin kazandırıldığından bahsetmektedir. Literatürde yapılan çalışmalarda bireysel, toplumsal, ulusal ya da evrensel değerler gibi genel değerlerden bahsedildiği görülmektedir. Bu araştırmadan elde edilen sonuçlar etkili vatandaşlık eğitiminde doğrudan gerekli olan değerleri ortaya koyması bakımından anlamlıdır.

Öğretmenlerin büyük bölümü programdaki değerleri etkili vatandaşlık için yeterli görmektedirler. Demirhan-İşcan ve Demir (2009) 2005 programına göre değerlerin öğretim programı ve öğrenci kitaplarında sadece yüzeysel bir şekilde ele alındığını tespit etmişlerdir. Ayrıca değerlerin daha çok bilgi düzeyinde sunulduğu görülmektedir. Bu durum etkili vatandaşlık eğitimi için olumsuz bir sonuç olarak değerlendirilebilir. 2018 programındaki değerler ise öğretmenler büyük bölümü tarafından etkili vatandaşl1k eğitimi için yeterli görülmektedir. Fakat bir kısmı da öğretmene saygı, hoşgörü, merhamet, milliyetçilik değerlerinin eklenmesi gerektiği üzerinde durmuşlardır.

Öğretmenler etkili vatandaşlık eğitiminde değerlerin yaparak-yaşayarak, rol model olarak ve gezi-gözlem yoluyla kazandırılmasının etkili olduğunu düşün- 
mektedirler. Hablemitoğlu ve Özmete (2012) çalışmasında etkili vatandaşlık eğitiminin uygulama odaklı olması gerektiği üzerinde durmaktadırlar. Som ve Karataş (2015) çalışmasında vatandaşlık eğitiminin uygulamaya dönük olması gerektiğinden bahsetmektedirler. Merey, Karatekin ve Kuş (2012b) Türkiye'de ve ABD'de vatandaşlık eğitimi kapsamında okullarda geziler, yarışmalar, tiyatro çalışmaları, sergiler gibi etkinliklerin gerçekleştirildiğini belirtirler. Şimşek, T1kman, Yıldırım ve Şentürk (2017) çalışmalarında öğretmen adayları vatandaşlık eğitiminin drama, film, video, slayt, günlük yaşamla ilişkilendirme, yaparak-yaşayarak öğrenme, somutlaştırma, örnek olay, farkındalık oluşturma, anlatım, yakından uzağa ilişkisi, beyin fırtınası, tartışma, rol oynama, gezi, model olma, gazete ve zihin haritaları yoluyla verilebileceğini belirtmişlerdir. Literatürdeki çalışmaların sonuçları ve bu araştırmadan elde edilen sonuca göre değerlerin daha çok uygulamaya yönelik olarak kazandırılmasının etkili vatandaşlık eğitimi için daha önemsendiği söylenebilir. Demirhan-İscan ve Demir (2009)'in çalışmasında da 2005 programına göre öğretim programında değerlerin beceri haline dönüştürülmesinin yeterli düzeyde olmadığından bahsedilmektedir. Bu durum yaparak-yaşayarak öğrenmenin önemini ortaya koymaktadır. Dolayısıyla literatürdeki bu çalışmanın sonucu ile bu araştırmadan elde edilen bulgunun çeliştiği söylenebilir.

Etkili vatandaşlık eğitiminde Sosyal Bilgiler öğretmenleri kendi rollerini rol-model olmak, yol gösteren olmak ve özverili olmak olarak düşünmektedirler. Sağlam (2012) çalışmasında ilköğretimde görev yapan öğretmenlerin etkili vatandaşlık yeterliliklerine ilişkin algılarının üst düzeyde olduğunu tespit etmiştir. Öğretmenlerin vatandaşlık eğitiminde rol model olmaları açısından bu sonucun önemli olduğu söylenebilir. Şen (2019) de çalışmasında etkili vatandaşlık eğitiminde değerlerin kazandırılmasında öğretmenin en önemli rolünün rol model olmak olduğunu belirtmektedir. Literatürdeki çalışmaların sonuçlarının bu araştırmadan elde edilen sonuçları desteklediği söylenebilir. Faiz ve Yazıcı (2018) ile Karasu Avcı ve Faiz (2018)'in çalışmalarında da uygun rol modelin değer eğitiminde kullanılması etkili bir yöntem olarak bulunmuştur.

Araştırmadan elde edilen sonuçlara dayanarak vatandaşlık eğitimi ve değerler ilişkini ele alan çalışmaların yeterli düzeyde yapılmadığı fark edilmiştir. Bu konuyu ele alan farklı çalışmaların yapılması alana katkı sağlayacaktır. Ayrıca öğretmenlerin vatandaşlık eğitimi ile ilgili konuları değerlerle ele alabileceği ve etkinliklerin uygulamalı olarak yapılmasına dikkat etmeleri gerektiği önerilebilir. Araştırmada Sosyal Bilgiler öğretmenlerinin etkili vatandaşlık eğitiminde 
değerlerin kazandırılmasında rol model olmaları ve yol gösterici olmaları üzerinde durulmaktadır. Bu nedenle öğretmenlerin değerleri yansıtan hal, hareket ve tavır sergilemeleri ve öğrencilere yol gösterici olmaları gerektiği söylenebilir. Değerlerin öğretilmesinde rol-model olmak önemli görüldüğünden ders kitaplarında ya da öğretmenler derslerinde uygun kişileri rol model gösterebilir. Sosyal Bilgiler Öğretim Programı'na etkili vatandaşlık eğitimini de destekleyici yeni değerler (fedakarlık, hoşgörü, merhamet...vb.) eklenebilir.

\section{Kaynakça}

Akbaş, O. (2004). Türk milli eğitim sisteminin duyuşsal amaçlarının ilköğretim II. kademedeki gerçekleşme derecesinin değerlendirilmesi (Yayımlanmamış doktora tezi). Ankara Gazi Üniversitesi Eğitim Bilimleri Enstitüsü, Ankara.

Akbaş, O. (2009). İlköğretim okullarında görevli branş öğretmenlerinin değer öğretimi yaparken kullandıkları etkinlikler: 2004 ve 2007 yıllarına ilişkin bir karşılaştırma. Kastamonu Eğitim Dergisi, 17(2), 403-414.

Andrews, R., Cowell, R., Downe, J., Martin, S. and Turner, D. (2008). Supporting effective citizenship in local government: Engaging, educating and empowering local citizens. Local Government Studies, 34(4), 489-507.

Balcı, F. A. ve Yanpar Yelken T. (2010). İlköğretim öğretmenlerinin "değer" kavramına yükledikleri anlamlar. Hacettepe Üniversitesi Eğitim Fakültesi Dergisi, 39, 81-90.

Beldağ, A. (2012). İlköğretim yedinci sinıf Sosyal Bilgiler dersindeki değerlerin kazanılma düzeyinin çeşitli değişkenler açısından incelenmesi (Erzurum ili örneği) (Yayımlanmamış doktora tezi). Atatürk Üniversitesi Eğitim Bilimleri Enstitüsü, Erzurum.

Berson, I. R. and Berson, M. J. (2003). Digital literacy for effective citizenship. Social Education, 67(3), 164-168.

Bohning, G., Hodgson A., Foote, T., Mcgee, C. and Young, B. (1998). Identifying and examining adolescents' moral values. Urban Education. 33(2), 264- 280.

Chandler, M. K. (2005). The effect of a character education program on elementary students' prosocial competence (Unpublished master's thesis). Lynn University.

Coombs-Richardson, R. and Tolson H. (2005). A comparison of values rankings for selected american and australian teachers. Journal of Research in International Education, 4, 263-277.

Correia, A. M. R. (2002). Information literacy for an active and effective citizenship. In White Paper prepared for UNESCO, the US National Commission 
on Libraries and Information Science, and the National Forum on Information Literacy, for use at the Information Literacy Meeting of Experts, Prague, The Czech Republic. Retrieved January (Vol. 20, p. 2014).

Creswell, J. W. (2012). Educational research: Planning, conducting, and evaluating quantitative. Upper Saddle River, NJ: Prentice Hall.

Çarkoğlu, A. ve Kalaycığlu, E. (2014). Türkiye'de ve Dünya'da vatandaşlık. İstanbul: İstanbul Policy Center.

Çelik, H. (2008). Cumhuriyet dönemi vatandaşlık eğitiminde önemli adımlar. Sakarya Üniversitesi Fen Edebiyat Fakültesi Dergisi, 10(1), 359-369.

Çelikkaya, T., Filoğlu, S. ve Öktem, N. S. (2013). Sosyal Bilgiler dersinde değerler eğitimi uygulamalarının öğretmenler tarafından uygulanma düzeyi. Journal of Social Studies Education Research, 4(1), 121-160.

Çengelci, T. (2010). İlkögretim beşinci sınıf Sosyal Bilgiler dersinde değerler ĕgitiminin gerçekleştirilmesine ilişkin bir durum çalışması (Yayımlanmamış doktora tezi). Anadolu Üniversitesi Eğitim Bilimleri Enstitüsü, Eskişehir.

Çevik Kansu, C. (2015). İlkokul 4. sınıf öğrencilerinde etkin vatandaşlık ĕgitiminin etkililiği (Yayımlanmamış doktora tezi). Ondokuz Mayıs Üniversitesi Eğitim Bilimleri Enstitüsü, Samsun.

Deer, F. (2008). Teachers and principals'perceptions of citizenship development of aboriginal high school students in the province of manitoba: An exploratory study (Unpublished doctoral thesis). University of Saskatchewan, Canada.

Demircioğlu, İ. H. (2008). Türkiye'de tarih öğretimi aktif vatandaşlık eğitimini desteklemekte midir? Tarih öğretmenlerinin görüşleri. (Ed. M. Safran ve D. Dilek), 21. Yüzyılda kimlik, vatandaşlık ve tarih eğitimi İçinde (s. 54-60), İstanbul: Yeni İnsan Yayınevi.

Demirhan İşcan, C. ve Demir, K. (2009). Vatandaşlık eğitiminde değerler ve değerler eğitimi. 1. Uluslararası Avrupa Birliği, Demokrasi, Vatandaşlık ve Vatandaşlık Eğitimi Sempozyumu Bildiri Kitabı İçinde (s. 137-146). Uşak: Pegem Akademi Yayıncılık.

Doğanay, A. (2005). Sosyal Bilgiler öğretimi. Ankara: Pegem Akademi Yayıncılık. Ersoy, A. F. (2007). Sosyal Bilgiler dersinde öğretmenlerin etkili vatandaşlık ĕgitimi uygulamalarına ilişkin görüşleri (Yayımlanmamış doktora tezi). Anadolu Üniversitesi, Eğitim Bilimleri Enstitüsü, Eskişehir.

Ersoy, F. ve Şahin, T. (2012). Sosyal Bilgiler ders kitaplarının değerler eğitimi yaklaşımları açısından incelenmesi. Kuram ve Uygulamada Eğitim Bilimleri, 12(2), 1535-1558. 
Evin, İ. ve Kafadar, O. (2004). İlköğretim Sosyal Bilgiler programının ve ders kitaplarının ulusal ve evrensel değerler yönünden içerik çözümlemesi. Türk Ĕ̈itim Bilimleri Dergisi, 2(3), 293-304.

Faiz, M. ve Yazıc1, K. (2018). Social Studies teacher candidates'views on the use of historical heroes in values education. International Journal of Eurasia Social Sciences, 9(33), 1897-1918.

Farmer, R. (2010). Values, Social Studies and reality. The Social Studies, 7(83), $52-55$.

Fraenkel J. R. and Wallen N. E. (2009). How to design and evaluation research in education. New York: McGraw-Hill.

Gedik Güney, E. (2010). Sinıf öğretmenlerinin değer yönelimlerinin ve öğrencilere aktarmak istedikleri değerlerin incelenmesi (Yayımlanmamış yüksek lisans tezi). Zonguldak Karaelmas Üniversitesi Sosyal Bilimler Enstitüsü, Zonguldak.

Hablemitoğlu, Ş. ve Özmete, E. (2012). Etkili vatandaşlık eğitimi için bir öneri. Ankara Sağlık Bilimleri Dergisi, 1(3), 39-54.

Halstead, J. M. and Taylor, M. J. (2002). Learning and teaching about values: A review of research. Cambridge Journal of Education, 30, 169-202.

Kan, Ç. (2009a). Değişen değerler ve küresel vatandaşlık eğitimi. Kastamonu Ĕgitim Dergisi, 17(3), 895-904.

Kan, Ç. (2009b). Sosyal Bilgiler eğitiminde küresel vatandaşlık. Pamukkale Üniversitesi Eğitim Fakültesi Dergisi, 26(26), 25-30.

Kan, Ç. (2010). Sosyal Bilgiler dersi ve değerler eğitimi. Milli Eğitim Dergisi, 187(3), 138-145.

Karasu Avc1, E. (2016). Sosyal Bilgiler dersinde değerler eğitiminde coğrafya disiplininin rolü. Araştırma ve Deneyim Dergisi, 1(1), 1-23.

Karasu Avc1, E. ve Faiz, M. (2018). 4. ve 5. sinıf sosyal bilgiler ders kitapları "etkin vatandaşl1k" öğrenme alanında yer alan becerilerin ve değerlerin incelenmesi. Uluslararası Sosyal Bilgilerde Yeni Yaklaşımlar Dergisi, 2(1), 1-21.

Kılıç-Şahin, H. (2010). İlköğretim okullarında Sosyal Bilgiler dersini yürüten 4. ve 5. sınıf öğretmenlerinin Sosyal Bilgiler Dersi Öğretim Programında yer alan değerlerin kazandırılmasına ilişkin görüşleri (Yayımlanmamış yüksek lisans tezi). Gazi Üniversitesi, Eğitim Bilimleri Enstitüsü, Ankara.

Kızılay, N. (2015). Sosyal Bilgiler öğretmenim: Bana göre iyi vatandaş. Turkish Studies, 10(11), 987-1006. doi: 10.7827/TurkishStudies.8468

Kurtdede Fidan, N. (2009). Öğretmen adaylarının değer öğretimine ilişkin görüşleri. Kuramsal Ĕ̈itim Bilim Dergisi, 2(2), 1-18. 
Leblanch, Brenda F. (2007). Teacher's perception, training, and implementation of character education: Implications for staff development (Unpublished doctoral thesis). George Mason University.

Ledford, A. T. (2005). A study of teachers' efficacy for teaching character education (Unpublished doctoral thesis). Regent University School of Education.

Lewis, J. G. (2007). The impact on teacher practice when character education is integrated into curriculum (Unpublished doctoral thesis). Boston College.

Marshall, M. N. (1996). Sampling for qualitative research. Family Practice, 13(6), $522-526$.

Merey, Z., Kuş, Z. ve Karatekin, K. (2012a). İlköğretimde vatandaşlık eğitimi: Karşılaştırmalı bir çalışma. Gazi Üniversitesi Gazi Eğitim Fakültesi Dergisi, 3(3), 795-821.

Merey, Z., Kuş, Z. ve Karatekin, K. (2012b). Türkiye ve ABD ilköğretim Sosyal Bilgiler Öğretim Programlarının değerler eğitimi açısından karşılaştırılması. Kuram ve Uygulamada Ĕ̈itim Bilimleri (KUYEB). Değerler Ĕ̆itimi Sempozyumu Ek Özel Sayısl, 12(2), 1613-1632.

Miethe, T. D. (2001). The validity and reliability of value measurements. The Journal of Psychology, 119(5), 441-453.

Miller, J. D. (1995). Scientific literacy for effective citizenship. (Ed. Robet E. Yager). Science/Technology/Society As Reform in Science Education (185-204), Albany: State University of New York Press.

Milli Eğitim Bakanlığı, (2018). Sosyal bilgiler dersi programı. Erişim adresi: http:// www.mufredat.meb.gov.tr

Moore, A. L. (2005). A case study of how an elementary school aged student receives and responds to character education (Unpublished doctoral thesis). University of Wyoming.

National Council For The Social Studies (NCSS), (2010). National curriculum standards for Social Studies: A framework for teaching, learning, and assessment. Washington, D.C.: NCSS Press.

National Council For The Social Studies (NCSS), (2012). Curriculum standards for Social Studies: Introduction. Erişim adresi: http://www.ncss.org/standards/ introduction

Nzahabwanayo, S. (2016). Citizenship and values education in Post-Genocide Rwanda: An analysis of the Itorero training scheme for high school leavers (Unpublished doctoral thesis). University of the Witwatersrand, Johannesburg.

Owens, V. (2005). Values disparity and academic achievement among ugandan adolescents. Journal Of Beliefs and Values, 26(3), 311-315. 
Patton, M. Q. (2014). Nitel araştırma ve değerlendirme yöntemleri. Mesut Bütün, Selçuk Beşir Demir (Çev. Ed.), 3. Baskıdan Çeviri, Ankara: Pegem Akademi Yayıncılık.

Phillips, R. (2003). History, citizenship and identity, past forward: A vision for school history 2002-2012 (Ed. R. J. Harris and M. Riley). London: Historical Association.

Raths, L. E., Harmin, M. ve Simon, S. B. (1966). Values and teaching: Working with values in the classroom. Columbus, $\mathrm{OH}$ : Charles Merrill.

Revell, L. (2002). Children's responses to character education. Educational Studies, $4(28), 421-431$.

Rokeach, M. (1973). The nature of human values. New York: The Free Press.

Safran, M. (2008). Sosyal bilgiler öğretimine bakış (Ed. B. Tay ve A. Öcal). Özel ögretim yöntemleriyle sosyal bilgiler ögrretimi İçinde (s.2-16). Ankara: Pegem Akademi.

Sağlam, H. İ. (2012). İlköğretim öğretmenlerinin etkili vatandaşlık yeterlik algılarının çeşitli değişkenler açısından incelenmesi. Sosyal Bilgiler Eğitimi Araştırmaları Dergisi, 3(2), 71-85.

Sarı, E. (2005). Öğretmen adaylarının değer tercihleri: Giresun Eğitim Fakültesi örneği. Değerler Ĕ̌itimi Dergisi, 3(10), 73-88.

Silfver, M. (2007). Gender differences in value priorities, guilt, and shame among finnish and peruvian adolescents. Sex Roles, 56(9-10), 601-609.

Sim, J. B. Y. and Low, E. L. (2012). Character and citizenship education: Conversations between personal and societal values. Asia Pacific Journal of Education, 32(4), 381-394.

Som, İ. ve Karataş, H. (2015). Türkiye'de vatandaşl1k eğitimi üzerine bir inceleme. Uşak Üniversitesi Ĕgitim Araştırmaları Dergisi, 1(1), 33-50.

Şen, A. (2019). Vatandaşlık eğitiminde değişiklik ve süreklilikler: 2018 Sosyal Bilgiler Öğretim Programı nasıl bir vatandaşlık eğitimi öngörüyor? Eğitimde Nitel Araştırmalar Dergisi, 7(1), 1-28. doi:10.14689/issn.2148$2624.1 .7 \mathrm{c} 1 \mathrm{~s} .1 \mathrm{~m}$

Şimşek, U., Tıkman, F., Yıldırım, E. ve Şentürk, M. (2017). Sosyal Bilgiler ve sınıf eğitimi öğretmen adaylarının gözünden vatandaşlık eğitimi: Nitel bir çalışma. Dicle Üniversitesi Ziya Gökalp Eğitim Fakültesi Dergisi, 32, 913-925.

Tahiroğlu, M. (2011). İlköğretim 4. sinıf Sosyal Bilgiler dersinde doğa sevgisi, temizlik ve sağlıkl olma değerlerinin ögretimi ve değerlere ilişkin öğrenci tutumlarının belirlenmesi (Yayımlanmamış doktora tezi). Gazi Üniversitesi Eğitim Bilimleri Enstitü, Ankara. 
Tay, B. (2009). Prospective teachers' views concerning the values to teach in the course of social sciences. Social and Behavioral Sciences, 1(1), 1187-1191. doi: 10.1016/j.sbspro.2009.01.214

Tezci, E. (2002). Oluşturmacı öğretim tasarım uygulamasının ilköğretim beşinci sınıf ögrencilerinin yaratıcılıklarına ve başarılarına etkisi (Yayımlanmamış doktora tezi). Firat Üniversitesi Sosyal Bilimler Enstitüsü, Elazığ.

Tezgel, R. (2006). Yeni ilköğretim Sosyal Bilgiler Dersi Öğretim Programı'nda insan hakları ve değer eğitimi. II. Uygulamalı Etik Kongresi Bildiri Kitabı, 637-645.

Thornberg, R. (2008). The lack of professional knowledge in values education, Teaching And Teacher Education, 24(7), 1791-1798. doi: 10.1016/j. tate.2008.04.004

Tokdemir, M. A. (2007). Tarih öğretmenlerinin değerler ve değer eğitimi hakkındaki görüşleri (Yayımlanmamış yüksek lisans tezi). Karadeniz Teknik Üniversitesi Sosyal Bilimler Enstitüsü, Trabzon.

Turnbull, J. (2002). Values in educating for citizenship: Sources, influences and assessment. Pedagogy, Culture \& Society, 10(1), 123-134. doi: $10.1080 / 14681360200200135$

Türkiye Büyük Millet Meclisi Araştırma Merkezi, (2011). Ülke anayasalarında vatandaşlık tanımları. Erişim adresi: https://anayasa.tbmm.gov.tr

Ulusoy, K. (2007). Lise tarih programinda yer alan geleneksel ve demokratik değerlere yönelik öğrenci tutumlarının ve görüşlerinin çeşitli değişkenler açısından değerlendirilmesi (Yayımlanmamış doktora tezi). Gazi Üniversitesi Eğitim Bilimleri Enstitüsü, Ankara.

Uğurlu, C. T. (2011). Avrupa Birliği ülkelerinde ve Türkiye'de vatandaşlık eğitimi. Elektronik Sosyal Bilimler Dergisi, 10(37), 153-169.

Üstel, F. (2005). Makbul vatandaşın peşinde II. Meşrutiyet'ten bugüne vatandaşlık eğitimi (5. baskı). İstanbul: İletişim Yayınları.

Veugelers, W. (2000). Different ways of teaching values. Educational Review, 25(1), 37-46. doi: 10.1080/00131910097397

Veugelers, W. and Kat, E. (2003). Moral task of the teacher according to students, parents and teachers. Educational Research and Evaluation, 9(1), 75-91. doi: 10.1076/edre.9.1.75.13543

Willemse, M., Lunenberg, M. and Korthagen, F. (2005). Values in education: A challenge for teacher educators. Teaching and Teacher Education, 21, 205217. doi: 10.1016/j.tate.2004.12.009 
Wright, A. (2005). On the intrinsic value of religious education. British Journal of Religious Education, 27(1), 25-28.

Yaşar, Ş. ve Çengelci, T. (2012). Sosyal bilgiler dersinde değerler eğitimine ilişkin bir durum çalışması. Uluslararası Avrasya Sosyal Bilimler Dergisi, 3(9), $1-23$.

Yazıc1, K. (2006). Değerler eğitimine genel bir bakış. Türklük Bilimi Araştırmaları, $19,499-522$.

Yazıcı, M. (2014). Değerler ve toplumsal yapıda sosyal değerlerin yeri. Fırat Üniversitesi Sosyal Bilimler Dergisi, 24(1), 209-223.

Yeşil, R. (2002). Okul ve ailede insan haklart ve demokrasi eğitimi. Ankara: Nobel Yayıncilik.

Yıldırım, K. (2009). Values education experiences of Turkish class teachers. A phenomological approach. Eğitim Araştırmalart-Eurasian Journal of Educational Research, 35, 165- 184.

Yıldırım, A. ve Şimşek, H. (2003). Sosyal bilimlerde nitel araştırma yöntemleri. Ankara: Seçkin Yayıncılık.

Yiğittir, S. ve Kaymakçı, S. (2012), Sosyal bilgiler dersi öğretim programı uygulama kılavuzunda yer alan etkinliklerin değer eğitimi yaklaşımları açısından incelenmesi. Ahi Evran Üniversitesi Kırşehir Eğitim Fakültesi Dergisi, 13(2), 49-73. 


\title{
Values Education in Effective Citizenship Education: Thoughts of Social Studies Teachers
}

\author{
Emine KARASU-AVCI, Assistant Professor. \\ Kastamonu University, Faculty of Education, Turkey. \\ eavci@kastamonu.edu.tr \\ http://orcid.org/0000-0002-3135-2557
}

Melike FAIZ, Corresponding Author, Assistant Professor.

Kastamonu University, Faculty of Education, Turkey.

mfaiz@kastamonu.edu.tr

http://orcid.org/0000-0001-8070-6086

Saim TURAN, Research Assistant.

Akdeniz University, Faculty of Education, Turkey.

turansaim@gmail.com

http://orcid.org/0000-0003-0298-8609

Article Type: Research Article

https://doi.org/10.34234/ded.655916

Received Date: 05.12.2019

Accepted Date: 01.04 .2020

Published Date: 25.06.2020

\section{Introduction}

A citizen is a person who has knowledge within the framework of his/her social rights and responsibilities, who has ideas about issues regarding the present and future of society and actively participates in decision-making mechanisms (Demircioğlu, 2008). Since the beginning of settlements, one of the greatest goals of societies has been to train individuals who internalize the expectations and necessities of society. Because it is only possible to maintain the continuity of the societies and having its need met by individuals who are attached to the society with a sense of belonging. 
Effective citizenship is the knowledge of one about his/her rights and the way to claim them. Effective citizenship is awareness of the responsibilities, and willingness of fulfilling them; and it is to respect the rights of other people. In democratic societies, individuals have the required citizenship characteristics in terms of knowledge, skills and values (NCSS, 2010).

One of the basic features that an effective and responsible citizen should have is adopting values (NCSS, 2012). Halstead \& Taylor (2002) describe the concept of value as principles guiding behavior, basic beliefs, and standards that are deemed to be good or desirable; Raths, Harmin, and Simon (1966) define value as actions that can be selected and repeated by considering many alternatives without belief, emotion, behavior and coercion that the individual is proud of. In addition, the concept of value can be expressed as a belief system that is used to explain social life (Yazic1, 2014) and also reflects social attitudes and expectations in the formation of citizen ship consciousness (Rokeach, 1973). The future of a society depends on the existence of individuals who embrace the values and act upon these values. Values are the power source for individuals to cope with problems and take action (MoNE, 2018). Values reflect social attitudes and expectations in the creation of the citizenship consciousness. Individuals who adopt values are needed both for the cultivation of effective citizens and for social continuity.

There is no doubt that schools, teachers and program makers have important duties to raise effective citizens. In our age, individuals are taught courses about citizenship education in order to enable them to adapt to the society in which they live correctly and most effectively. The good and effective citizen's acquisitions, skills and behaviors reveal the necessity of the right education and training tools and an appropriate curriculum (Phillips, 2003; Kan, 2009).

The future of a society depends on the existence of individuals who embrace values and fleshes out these values. Values are the power source for individuals to cope with problems and take action (MoNE, 2018). Another feature of values is the ability to unite individuals around them. This can be explained by the fact that the values are formed and anonymized over time. Individuals who embrace values are needed for both; upbringing of effective citizens and for social continuity. As a matter of fact, in order for the citizenship to be fully differentiated by the needs, tendencies and developments, the individual must learn the values of the society in which S/he lives and internalize them. Values are common ideas, moral principles and social rules developed over time and adopted by the 
majority of the society in order to maintain the society or group. Values reflect social attitudes and expectations in the formation of citizenship consciousness. Individuals who embrace values are needed for both; upbringing of effective citizens and for social continuity.

Social Studies course, is a course that deals with citizenship education within its scope. It can be said that the purpose of the emergence of the Social Studies course is to train individuals as citizens who are compatible with the society in terms of their aims and structure. When considering that the basic aim of this course is citizenship education, then the importance of values and values education, which is an important pillar of Social Studies course, in developing effective citizen profile becomes evident. In order to achieve this goal, it is necessary to reveal the opinions of Social Studies teachers about values and values education in effective citizenship education.

As the main purpose of the Social Studies course is the citizenship education, the development of an effective citizen profile means that the importance of values and teaching values is an important aspect of the Social Studies course. The problem statement of the study was determined as, "What are the thoughts of social studies teachers about values and values education in terms of effective citizenship education?"

\section{Method}

In this research, the phenomenological research model was preferred among qualitative research models because the opinions of Social Studies teachers were discussed based on their experiences. Phenomenology is an inquiry-based method that describes the phenomenon consisting of experiences of independent participants (Creswell, 2012; Fraenkel \& Wallen, 2009). The study group of the research, consist of Social studies teachers from different cities of Turkey who agreed to participate voluntarily.

The study group of this research consists of 19 Social Studies teachers working in different places (village, town, district, province). The reason that the participants in the research were selected from different places is that they would have different experiences in different places. In this context, convenience sampling method was utilized from easily accessible sample types. Convenience sampling is a type of sampling that selects people who are convenient in terms of time, money, transportation, etc. to the researcher and willing to participate in the research for the time being (Creswell, 2012; Marshall, 1996). 
In this study, data were obtained through an interview form. The interview form was designed as a structured interview form. The following questions were asked to the Social Studies teachers in the research:

1. What is the relationship between values and citizenship education?

2. What are the values of an effective citizen?

3. What values in the 2018 Social Studies Curriculum are more important for effective citizenship education?

4. Are there any values that need to be added to the 2018 Social Studies Curriculum for effective citizenship education? If so, what are these values? If not, indicate why.

5. In what ways should values be acquired for effective citizenship education?

6. What are the roles of Social Studies teachers in providing values for effective citizenship education?

The data obtained were analyzed by descriptive analysis in NVIVO 11 program. Descriptive analysis is aimed to present the findings to the reader in a summarized and interpreted form.

Validity in qualitative research; is that researchers, participants and readers understand and make the same inferences from the findings obtained from the analysis of data (Creswell, 2012). In this study, validity was aimed to be obtained by explaining the findings in detail and by having the direct opinions of the teachers about the findings. Reliability in qualitative research; it is described as analyzing the data obtained by more than one encoder and reaching a common decision in cases where there is a difference of opinion (Creswell, 2012). In this research, a number of researchers took part in the process of coding, classifying and category development of data. Differences in opinions were resolved by gathering the researchers and reaching a common decision.

\section{Results and Discussion}

Teachers' thoughts on the relationship between values and citizenship education were grouped under 4 themes. These themes are directly related, interrelated, complementary and have positive effects. According to the teachers, the most important values that an effective citizen should have are the values of patriotism, responsibility, diligence and honesty respectively. According to the teachers, 15 different values are important for effective citizenship education 
in Social Studies Curriculum. The most frequently repeated values are patriotism, honesty and diligence. The opinions of teachers about the values to be added to the social studies curriculum were grouped under two themes. The values in the program are sufficient and there are values that need to be added. Teachers' opinions on how to provide values were grouped under four themes. These themes are; by-living, being a role model and as a trip-observation. The opinions of teachers about their role in the acquisition of values are grouped under three themes, which are; to be role models, to be guided and to be selfless.

\section{Pedagogical Implications}

Social Studies teachers think that there is a relationship between citizenship and values are directly linked to each other, that they intertwined and affect each other. The results also show that teachers think equality and honesty are the values that required for effective citizenship. Another result of the study is that Social Studies course contributes to effective citizenship education with similar values. Teachers believe that the values given in the Social Studies Curriculum are generally sufficient for effective citizenship education. Based on the results obtained from the study, it is safe to say that more studies on citizenship education should be conducted. Conducting different studies dealing with this issue will contribute to the field. Especially research that determine the relationship between citizenship and values education. 